\title{
EXPLORATION OF LEGISLATIVE REMEDY FOR PREJUDICIAL CHANGES IN SENIOR SHARES
}

\author{
EIVIN R. LATTY*
}

$\mathrm{I}$

N RECENT YEARS PERHAPS NO AREA of corporation law has called forth more criticism than that concerning recapitalizations which involve an alteration of the relative rights of classes of shareholders. ${ }^{1}$ The law of corporate recapitalization is largely a development of the last fifteen years. Older decisions exist, but newly invented strategies and recent corporation statutes make this virtually a new branch of corporation law. Criticism of the more objectionable features of this law has focussed on a typical pattern in the recapitalization scheme, i.e., the arrearage elimination pattern. The pattern is roughly as follows:

Corporation $\mathrm{X}$ has outstanding preferred and common shares. Voting power over election of directors rests with the common; also, common's votes are necessary for any formal reduction of capital, which in turn may have a bearing on the creation of a lawful dividend-payment fund. Until recently, the corporation's business has not been profitable, and no dividends have been paid for some years. Since the preferred is "cumulative," a formidable arrearage has piled up ahead of the common. Thus, although the corporation shows promise of making enough profits to pay some or all of the preferred's dividend priority, it will be years before any dividends can be paid to the common, because the preferred's arrearage must

* Professor of Law, Duke University School of Law.

1 Ballantine, Corporations 525-26, 655-66 (rev. ed., 1946); Becht, Corporate Charter Amendments: Issues of Prior Stock and the Alteration of Dividend Rates, 50 Col. L. Rev. 900 , 943 (1950); Becht, Changes in the Interests of Classes of Stockholders by Corporate Charter Amendments, 36 Cornell L.Q. 1, 30 (1950); Becht, Alterations of Accrued Dividends, 49 Mich. L. Rev. 363, 370, 379, and 49 Mich. L. Rev. 565, 582-86, 588-94 (1951); Dodd, Fair and Equitable Recapitalizations, 55 Harv. L. Rev. 780 (1942); Dodd, Accrued Dividends in Delaware Corporations-From Vested Right to Mirage, 57 Harv. L. Rev. 894 (1944); Dodd, Recapitalization Plans Involving Funding of Accrued Dividends, Am. Bar Ass'n, Proceedings of the Section of Corporation, Banking and Mercantile Law 26 (1945); Lattin, A Primer on Fundamental Corporate Changes, 1 West. Res. L. Rev. 3 (1949); Latty, Fairness-The Focal Point in Preferred Stock Arrearage Elimination, 29 Va. L. Rev. 1 (1942); Walter, Fairness in State Court Recapitalization Plans-A Disappearing Doctrine, 29 B.U.L. Rev. 453 (1949); The Rights of Cumulative Preferred Stockholders under the Public Utility Holding Company Act, 52 Harv. L. Rev. 1331, 1336-37 (1939); Intraclass Discrimination in the Elimination of Accrued Dividends, 55 Harv. L. Rev. 1196, 1200 (1942); Elimination of Accrued Dividends on Preferred Stock, 33 Ill. L. Rev. 212, 214 (1938); Scaling-Down of Arrearages on Cumulative Preferred Stock, 4 Univ. Chi. L. Rev. 645, 648 (1937). 
be paid in full before the common gets anything. If some way can be found to circumvent these arrearages, the common can get dividends right now, while the sun is shining; on the other hand, if the common does not make hay now, it may find that the sun has gone behind the clouds just before the arrearages are satisfied. Maybe the thing to do is eliminate those arrearages. While we are about it, we may as well change the preferred's dividend rate downward and alter that troublesome "cumulative" right. Of course, we want a solid majority of the preferred to vote for this idea", as the corporation statute requires; moreover, even if the preferred is nonvoting, one cannot be sure that a court would permit the alteration of the rights of a class without the vote of that class. Anyhow, a big favorable vote looks good. So, the directors prepare a plan along the above lines. However much the details vary, one feature remains the same: the arrearages are to be handled in a way that will not prevent payment of current dividends to the common, subject only to the condition that they be first paid to the preferred (if the old preferred, as changed, still remains "preferred" at all).

The plan is put to stockholders' vote and, interestingly enough, nearly everybody who takes pains to vote, that is, to mail back a proxy, approves the plan.

Some of the preferred shareholders, however, dissent. They feel that "The Plan" is a steal, a device to slice the corporate melon not only in a manner that gives them slices of different shapes (with an undue proportion of rind), but also-and this is what counts-a much smaller slice. "Look," they say, "the plan takes away from our class ten years' accrual of unpaid dividends, amounting to $\$ 70.00$ per share, and takes away other rights, and in return for these lost rights, the plan gives each preferred share a $\frac{1}{2}$ share of newly created Class B common, nonvoting, so that each share of old preferred ends up in one share of trimmed-down new preferred and a $\frac{1}{2}$ share in a prolific junior equity class." "But consider," says the common, "that the plan provides that we old common shareholders, heretofore holding 100,000 shares of common, are now to be cut in half, cut down to 50,000 shares of sole-voting Class A common." The preferred shareholders remain unconvinced; they fail to see that common's consent to give the preferred a $\frac{1}{11}$ share in the equity (5000 shares out of the 55,000 aggregate shares of equity stock), and a nonvoting equity at that, ${ }^{2}$ is much compensation for what they have given up.

Moreover, the disgruntled preferred shareholder starts to calculate on

2 I do not mean to intimate that conferring additional voting power on the preferred really improves an otherwise unfair plan. 
the basis of a factor crucial to holders of a proprietary interest in a continuing business enterprise: how will the change affect the division of earnings between shareholder classes? First, he makes his calculation on the basis of the current earnings. Projecting these he finds that he would have been better off in his old position, which entitled him to the entire dividend distributions for many years. The fact that his class now owns a portion of equity stock does not begin to make him whole. Not until he hypothesizes earning power beyond all dreams does the projected return on the equity stock compensate him for what he gave up. At that point he will note that if corporate earning power is that good, there was no need to change his arrearage rights in the first place.

The disgruntled preferred shareholder may then turn to the courts for redress. His first argument will probably be that the corporation lacked "power" to alter his rights, despite the majority votes of stockholders. He is likely to lose. This power can probably be found in most states by virtue of: (1) the "reserved power" of states over corporate charters and statutes, (2) the clearly expressed or judicially interpreted language of charter amendment statutes, (3) "appropriately" drafted clauses in the charter itself, (4) the coercive effect of the nearly-everywhere recognized power to create a new class of prior preferred even for the sole purpose of exchanging it for existing senior classes, or (5) the resort to phony merger with a wholly-owned subsidiary or convenient affliated corporation. ${ }^{3}$

So the disgruntled shareholder will resort to another argument: the proposed changes should be enjoined by a court of equity because they are unfair to his class. Some years ago when recapitalization law was in a more formative stage, I ventured the opinion that courts were beginning to judge the fairness of a recapitalization. ${ }^{4} I$ thought that $I$ saw, in some of the question-begging "vested rights" rationales used by courts which found corporate "power" lacking, a realization of the unfairness in the plan involved; 5 and I detected hope even in the lip service paid to fairness in some cases where the courts had upheld recapitalizations through phony merger. One might have hoped that recapitalization law would follow the course of corporate reorganization law, where the altered seniors are creditors. Even before the federal statutes of the thirties required reorganizations (relabelled "bankruptcy" proceedings) to pass a judicial determination of "fair and equitable," courts of equity had recognized a

3 An exhaustive and excellent survey of a corporation's power to change the relative rights of shareholders is to be found in the articles by Professor Becht, op. cit. supra note 1 .

'Latty, op. cit. supra note 1.

- Ibid., at 48. 
"fair and equitable" requirement. And even in these cases, lower courts of yesterday approved plans which by today's standards would be viewed as unfair under the "substantial equivalence" rule whereby the senior is expected to pick up in new rights the substantial equivalent of what he gives up.

But hopes that a similar evolution would take place in the recapitalization field have been somewhat dimmed by subsequent judicial developments. It is true that one rarely finds flat judicial statements that fairness is irrelevant. ${ }^{6}$ Some courts have even invalidated recapitalization plans on grounds of unfairness. ${ }^{7}$ But one may also find pronouncements that a plan is fair where fairness in the reorganization sense is difficult to find ${ }^{8}$ or application of a "fairness" standard which makes nothing short of fraud unfair, ${ }^{9}$ or even discussions of the pozver of a corporation to alter the relative

- But see Franzblau v. Capital Securities Co., 2 N.J. Super. 517, 64 A. 2 d 644, 649 (1949).

' Wessel v. Guantanamo Sugar Co., 134 N.J. Eq. 271, 35 A. 2d 215 (1944), aff'd, 135 N.J. Eq. 506, 39 A. 2d 431 (1944). Despite preferred's vote for the plan by a ratio of about 7 to 1 , the court disapproved of the plan as being "wholly for the benefit of the common." See discussion in Ballantine, Corporations 658-60 (rev. ed., 1946).

${ }^{8}$ Western Foundry Co. v. Wicker, 403 Ill. 260, 85 N.E. $2 d 722$ (1949). The court said that the plan was fair because (1) $97 \%$ of the preferred had voted for it, (2) there was no earned or paid-in surplus from which current dividends could be paid to preferred shareholders, (3) the common were giving up $50 \%$ of the par value of their common shares, (4) the allegedly aggrieved non-assenting preferred stockholder could not complain because he also owned common. None of these factors, of course, come even close to meeting the basic tests of fairness, viz., whether the seniors are getting the substantial equivalent of what they are giving up. Of the four grounds above mentioned, the only one that has any weight is the high vote of the aggrieved class, about which more in a moment. There was no discussion of earning power, which in any careful analysis of fairness is the keystone. See observations upon this case by Walter, op. cit. supra note 1 , at 479-82.

' See Porges v. Vadsco Sales Corp., 27 Del. Ch. 127, 32 A. 2d 148 (1943). The proposed plan involved an elimination of all arrearage and a slicing of the preferred's dividend to just over $\frac{1}{3}$ of what it was. In return the preferred were to get about half the common stock. Obviously the fairness of the plan depended upon the earning power of the corporation. But earnings over any significant period of years, either before or after the adoption of the plan, did not even equal the preferred's old annual earnings priority. See data on Universal Laboratories, Inc., the new name of the corporation, in Moody, Manual of Investments 1771 (1950) and 2203 (1951). Nonetheless, the court approved the plan without so much as a discussion of earnings. It said that the unfairness which would prevent approval of the plan "must be of such character and must be so clearly demonstrated as to impel the conclusion that it emanates from acts of bad faith, or a reckless indifference to the rights of others interested, rather than from an honest error of judgment." Ibid., at 133 and 151.

And see Barrett v. Denver Tramway Corp., 53 F. Supp. 198 (D. Del., 1943), aff'd, 146 F. 2d 701 (C.A. 3d, 1944), for an extension of the Delaware "unfairness" rule to a plan which did not even give the preferred a share in the junior equity in return for their loss of arrearage. No analysis of earning power was necessary since the preferred got no new claim on earnings. The federal court, applying the Delaware test, found the plan not unfair because it was not fraudulent. It was not fraudulent because "management is made up of men of integrity, honesty, and well-deserved reputation in the community in which they live." Ibid., at 201. This might be called the Solid Citizen Test of fairness. See also, Zobel v. American Locomotive Co., 44 N.Y.S. $2 d 33$ (Super. Ct., 1943). 
rights of classes of shareholders without any mention of fairness at all..$^{10}$ The height of disregard of fairness was probably achieved in the Louisville Railway recapitalization ${ }^{10_{a}}$ where the preferred's dividend was reduced from $\$ 5$ to $\$ 4$, about $\$ 100$ of arrearages were wiped out and, in return for all this sacrifice, the preferred was given $\$ 2.50$ in cash. One is startled to find a banker testifying in that case, as the court reports, that "the preferred shareholders will receive the equitable equivalent of what they previously had."10b To the writer, this appears to be a caricature of the substantial equivalence doctrine as we know it in reorganizations.

Since, then, many state courts presently make unfair recapitalizations possible, the question arises whether legislation offers promise of remedial action. However, it may be argued that there is no need for legislative concern; that senior shareholders whose rights and values are scaled downward have the best possible remedy in their own hands: they can vote against the plan. If they vote for plans unfair to them, that is their own folly. True, if the vote was obtained by fraudulent misrepresentation, a court should and will interfere; hence, there is good reason for the Delaware attitude that if there is no fraud, voting settles the matter.

The foregoing, so-called liberal, view cannot be dismissed summarily. It avoids restraints, and leaves everybody free and treated equally, although, to paraphrase George Orwell, it may turn out that some are more equal than others. However, despite this appeal to strong American tradition, one may point out that such liberalism is not the old traditional American way of corporate life. Early American tradition could better be phrased as follows: Thou shalt not amend the corporate contract, directly or by merger or otherwise, so as to alter the relative rights of the shareholders without unanimous consent. Traditional restraints on corporations, of course, went far beyond the narrow field of corporate contract alteration; they included restraints on corporate size, range of corporate ac-

${ }^{10}$ Sherman v. Pepin Pickling Co., 230 Minn. 87, 41 N.W. 2d 571 (1950). Cf., Janes v. Washburn Co., 326 Mass. 356, 94 N.E. $2 d 479$ (1950), where the court struck down a direct charter amendment plan for lack of power under the pertinent statutes without discussion of fairness. Query whether this still leaves open the merger device, even the phony merger with a subsidiary corporation. No case had yet held that this device is invalid, even in those jurisdictions where the direct charter amendment method is unavailable, although one lower court decision intimated that the phony merger will not work. Anderson v. Cleveland-Cliffs Iron Co., 54 Ohio L. Abs. 65, 87 N.E. 2d 384 (C.P., 1948). Other recent Ohio cases have discussed pozver, not fairness, and make the existence of power turn on some "nice" distinctions. Wheatley v. A. I. Root Co., 147 Ohio St. 127, 69 N.E. 2d 187 (1946); Schaffner v. Standard Boiler \& Plate Iron Co., 150 Ohio St. 454, 83 N.E. 2d 192 (1948). See discussion by Lattin, op. cit. supra note 1.

${ }^{10 a}$ Donohue v. Heuser, 239 S.W. 2d 238 (Ky., 1951).

10b Ibid., at 246. 
tivities, range of geographical operations, indebtedness power of management, power of majorities to sell out or make other fundamental changes, unusual voting features, to mention but a few. ${ }^{11}$

The weight of the liberal argument will vary with the kind of legislative proposal. If the suggestion is merely to remove some existing legal restraint on the power of directors to pay dividends out of current net profits despite an existing deficit, one of the pressures on the preferred to vote for even an unfair plan will be largely eliminated, for the directors cannot then tell the shareholders that a change in the corporate contract is necessary to make dividends legally possible. At present, this restraint can be removed only by the common shareholders' assent to a capital reduction, and common is "free" to refuse this assent.

Even if the legislation requires that a plan be approved by a court as "fair and equitable," thus including a more drastic interference with the freedom of shareholders to vote as they please and to have that vote be the final determinant, the realities of the sponsorship and presentation of recapitalization plans may amply justify the interference. The pressures which enable sponsors to round up the required number of votes are sufficiently formidable to justify doubt as to whether the vote is really the best expression of free choices freely made.

\section{The Pressures}

First, even the sophisticated find it difficult to measure the relative gains and losses of a senior class in a recapitalization. That is true of even the simplest plan, a "one stock recapitalization," where all shareholders take only shares of a single class of new common. But the sponsors can make their plan highly complex, with many classes of stock and almost unweighable features. At this point the liberal view may interject: it is not the function of law to protect a man from his own ignorance, folly or lack of expertise. Actually, the law does just that in scores of instances, for example, the sales doctrine of implied warranty. Arguably, it is the housewife's own folly in not asking for an express guarantee when she bought that defective pressure cooker, or her own ignorance in not knowing what defects to look for, or, in failing to secure the services of an expert to examine the article. The shareholder voting on a recapitalization plan is not unlike the housewife. Indeed, in reorganization law, both judicial doctrine and the statutes reflect the security holder's need for greater protection

${ }^{11}$ See Mr. Justice Brandeis' dissenting opinion in Louis K. Liggett Co. v. Lee, 288 U.S. 517,541 et seq. (1933). 
than that given by his right to vote..$^{12}$ Certainly there is no strength in the contention that reorganizations differ because they involve "creditors"; a preferred shareholder with dividend and liquidation priorities is as much a senior over common as is a creditor. Moreover, reorganization law itself requires that standards of fairness be applied not only between creditors and shareholders but also between senior and junior shareholders.

The difficulty of pin-pointing the inequity in a recapitalization plan may account for the impressive majority votes that sponsors manage to muster. One recalls that the reorganization plan of the Los Angeles Lumber Products Company, which eventually led to the famous Supreme Court landmark decision, was pronounced unfair to the bondholders not only by the Supreme Court but by every writer who has ever commented upon it. Nevertheless it was approved by over $92 \%$ of the bonds. ${ }^{13}$

The American Bar Association's proposed revised (1950) Model Business Corporation Act contains no provision for judicial review of recapitalization plans. It is my understanding that the drafting committee did not believe that the average trial judge had sufficient understanding of recapitalization plans to justify that kind of power. If this is true it is rather strange to expect more of the average stockholder.

Second, the information submitted to shareholders, while perhaps not so inadequate as to amount to fraud, may yet be sufficiently inadequate to justify one in questioning whether the favorable vote is meaningful. Mr. Justice Stone's classic opinion in the American Tobacco stock purchase plan case ${ }^{14}$ is a strong reminder that when stockholders are not given all the facts necessary to make an intelligent choice, their vote cannot be considered the final determinant. The importance attached to earnings analyses in reorganization law suggests that without such information it is impossible to calculate how much is lost or gained by seniors' alterations. But a truly informative earnings analysis is hardly ever set forth in the literature soliciting approval of a plan of recapitalization. Even in solicitations that fall within the SEC Proxy Regulations, the shareholder typically gets no earnings analysis other than what he can make out from the required comparative profit and loss statement.

Third, even if the shareholder is dimly aware that he cannot determine the fairness of the plan from the information supplied him, still he does not

12 Frank, Some Realistic Reflections on Some Aspects of Corporate Reorganization, 19 Va. L. Rev. 541,569 (1933).

${ }^{13}$ Case v. Los Angeles Lumber Products Co., 308 U.S. 106, 111 (1939).

14 Rogers v. Guaranty Trust Co., 288 U.S. 123, 133 et seq. (1933). Although Stone's opinion was a dissent, it was the only opinion expressed on the merits, the majority opinion turning on a procedural point. 
quite know what it is that he does not know. The political voter is under somewhat the same handicap but there is no help for that, short of horrible alternatives. Moreover, the political voter has the benefits of all the "enlightenment" with which challengers eagerly supply him in their zeal to unseat the rascally incumbents. There is no real counterpart to political elections in the corporate democracy, short of sporadic proxy fights.

Fourth, the stockholder receiving a proposal from management can hardly be expected to take a wary attitude. If the law affords protection to the housewife purchaser even in the traditionally arm's-length sales transaction, it would seem well within reason to consider legișlative proposals for comparable assurance to the much less suspicious stockholder who looks to his own management for guidance. Those with misgivings about paternalism must realize that the stockholder already finds himself in a paternalistic institution where mere solicitation by those "who know best" is a strong pressure. The simple statement that "your Board of Directors has formulated a plan which it believes to be fair and financially sound"15 goes far to allay the stockholder's qualms.

Fifth, recapitalization plans may deliberately use the corporation's deficit to induce seniors to make sacrifices for the benefit of juniors. The solicitation literature tells the seniors that if the plan is approved, the way will be open to pay them dividends immediately but that if the plan is not adopted the existing deficit will prevent distribution. What the stockholders are not told is that a capital reduction paving the way for dividend payments could be effectuated without substantial alteration of rights. True, the common would have to vote for it, but it is by no means clear that common would not vote for it, since continued failure to pay dividends on the cumulative preferred would only increase the arrearage ahead of the common.

Sixth, if no deficit exists on which to base pressure, a deficit can perhaps be produced by a change in accountancy methods. When Crucible Steel Company of America submitted its arrearage elimination plan in 1940, the solicitation literature emphasized that the plan would eliminate a deficit of some $\$ 29,000,000$. However, this deficit had been achieved by plant write-downs and adjustments in depreciation reserves which reduced balance sheet valuations from $\$ 59,000,000$ to $\$ 19,000,000$; thereby a previously shown earned surplus of some $\$ 8,000,000$ on the December 31,1939 balance sheet was turned into a deficit of some $\$ 32,000,000$ in the January

${ }^{15}$ Letter from the Chairman of "Your Board of Directors" to the stockholders of Crucible Steel Company of America (Aug. 5, 1940), p. 6. The solicitation was for an arrearage-eliminating merger with a subsidiary. 
1, 1940 balance sheet. ${ }^{16}$ (1940 earnings reduced the deficit to some $\$ 29,000,000$.) Now, it may have been good accountancy to revalue these assets but one cannot fail to note the coincidence of the newly created deficit with the promulgation of a plan of arrearage elimination..$^{17}$

Seventh, if the merger technique is used, solicitation literature will frequently state that the merger will increase operating efficiency and effect various economies. ${ }^{18}$ Management's statements on such a business matter naturally carry great weight with the shareholders.

Eighth, the solicitation will nearly always declare that present arrearages impair credit and impede financing. Such a statement is a fractional truth, if any, ${ }^{19}$ yet one with sufficient plausibility to elicit the stockholders' assent. The only financing which arrearages seriously impede is the issuance of junior shares or, perhaps, of senior securities convertible into equity shares. It is significant that recapitalizations eliminating arrearages have not been followed by any such financing.

One may strongly doubt, then, that here is a situation where the vote of a majority must be accepted as the final expression of whether something is best or even desirable.

\section{Legislative Possibilities}

Reflection of legislative possibilities suggests a fairly wide range of potential remedies, particularly if administrative action is included.

1. Perhaps the most obvious suggestion is to take the cue from the field of corporate reorganization and require that, either before or after putting the plan to stockholders' vote, the corporation shall petition the court for a determination that the plan is "fair and equitable."

${ }^{16}$ Ibid., at 1, 16-17.

${ }^{17}$ Similarly, in the Denver Tramway case, the court reports that the corporation's balance sheet "reflects a surplus of $\$ 1,155,151.18$; a note attached, however, indicates a deficit of approximately $\$ 4,000,000$." Barrett v. Denver Tramway Corp., 53 F. Supp. 198, 199 (D. Del., 1943).

18 Proxy Statement of Jones \& Laughlin Steel Corporation (July 22,1941) p. 1 (sent to stockholders in connection with solicitation of proxies to vote for the company's 1941 merger with subsidiaries).

19 "The arrangement is not in the interest of the company, as the accrued dividends are not a debt of the company and do not affect its financial position and solvency." Boyer, J., in Re St. Lawrence Corp. and Mayr, [1948] 2 D.L.R. 107, 108 (Quebec Super. Ct.).

${ }^{20}$ Cr. Bankruptcy Act $\$ 174,30$ Stat. 544 (1898), as amended, 11 U.S.C.A. $\$ 574$ (1946). The Public Utility Holding Company Act of 1935 also provides, with respect to plans making corporate changes to comply with $\$ 11$ (b) of that Act, for submission to the court for approval if "fair and equitable." 49 Stat. 820 (1935), as amended, 15 U.S.C.A. $\$ 79 \mathrm{k}$ (e) (1951). For a comparable requirement of "just and reasonable," see Railroad Modification Act, 62 Stat. 163 (1887), as amended, 49 U.S.C.A. $\$ 20$ (b) (1951). 
be made that (1) this would throw a heavy burden on courts, since no dissenter may care to question the plan;21 and (2) perhaps state judges are not qualified to exercise this power. ${ }^{22}$ However, the burden cast on courts may be justified by the seriousness of present deficiencies in the law. As for judicial ineptitude, if this means that bad plans would get judicial approval, the situation could hardly be worse than at present. If, on the other hand, fair plans which should be approved encounter judicial veto, the result would be maintenance of the status quo-and no one as yet has demonstrated the need, ordinarily, for arrearage elimination even in fair plans. ${ }^{23}$ In the rare case where a real need can be shown, judicial veto is unlikely if the plan bears any semblance of decency.

In any event, direct legislative precedent is not lacking. Section 221 of the Dominion Companies Act of Canada, 1934, provides that when a "compromise or arrangement (recapitalization) is proposed . . . affecting the rights of ... shareholders," the designated judge may, on application of the company or of a shareholder, order a meeting; if the shareholders by a three-fourth vote of each class vote for the proposal, "such compromise or arrangement may be sanctioned by the said judge." "While the words "fair and equitable" are not used, we note that a Canadian company's letter to stockholders in connection with a recently proposed plan declared: "One of the essential elements of any such plan is that it provides fair and equitable treatment for each class of shareholders involved, having regard to their position and rights in the enterprise." ${ }^{25}$ The very existence of such judicial supervision seems to have a marked effect on the plans proposed by Canadian companies; exercise of the supervisory power improves them still more. A few years ago, St. Lawrence Paper Mills Company Limited had outstanding about $\$ 12,500,000$ of $6 \%$ preferred, par $\$ 100$ per share, with arrearages of about $\$ 60$ per share; a "compromise or arrangement" was proposed which, without cutting down the preferred's dividend rate or even changing other relative rights except arrearages,

${ }^{21}$ Becht, Alteration of Accrued Dividends: II, 49 Mich. L. Rev. 565, 588 (1951).

${ }_{22}$ See remarks supra p. 765; Dodd, Recapitalization Plans Involving Funding of Accrued Dividends, Am. Bar Ass'n, Proceedings of the Section of Corporation, Banking and Mercantile Law 26, 39 (1945).

${ }^{23}$ For a good rebuttal of the alleged need for arrearage elimination in a specific case, see Maine Central Railroad Company Securities Modification, 275 I.C.C. 261 (1950), under the Railroad Modification Law, $\S 20$ (b) of the Interstate Commerce Act, 62 Stat. 163 (1887), as amended, 49 U.S.C.A. $\S 20$ (b) (1951).

24 Statutes of Canada, Parts I-II, $24 \& 25$ Geo. V, c. 33, at $\$ \S 122(1)$ and (2) (1934). (Emphasis added.)

${ }^{25}$ Letter from St. Lawrence Paper Mills Co., Ltd. (Dec. 1, 1947) to stockholders in connection with solicitation of proxies for a vote on a recapitalization. 
gave each preferred holder, in satisfaction of the arrearages, a share of newly-created second preferred, with voting rights, entitled to cumulative dividends of $\$ 2.00$ per year ahead of the common and to a liquidation priority of $\$ 65$ a share..$^{26}$ Fair as that plan was in comparison with American recapitalizations, the court found it unfair to the preferred and made "for the sole benefit of the common stockholders."27 A new plan was proposed which raised the new preferred's dividend rate to $\$ 2.40$ and included a stiff sinking fund requirement calculated to retire the second preferred rather early if earnings went well. I understand that the second plan was sanctioned by the court.

In England, recapitalizations are likewise subject to judicial supervision. ${ }^{28}$

2. A variant of the above judicial supervision would require that a plan of recapitalization, when challenged by a stockholder, pass the test of "fairness," rather than the fraud test or some variant of the Delaware Solid Citizen Test. ${ }^{28 a}$ Here, the path has been blazed by the Nebraska legislature which, in 1951, amended its corporation laws so as to give corporations the power to make changes in outstanding shares but at the same time provided a safeguard against abuses:

In case of any proposed amendments of the articles of any corporation, changing the existing priority rights, or provisions of any class of preferred shares outstanding, any shareholders adversely affected, aside from all rights as provided in this act, may apply to any court of competent jurisdiction to restrain and enjoin the corporation from any such amendments on the grounds of fraud or unfairness. On the filing of such application the court shall, upon notice to all the stockholders, hold a hearing upon the issues of the alleged fraud or unfairness of the proposed amendment at which all shareholders shall have the right to appear and produce evidence upon the issue. After such hearing the court shall enjoin any of the proposed amendments if the proponents of the amendment fail to show that, to a reasonable probability, they are fair, just, and equitable to all shareholders affected thereby..$^{29}$

A noteworthy feature of this legislation is that it places on the proponents of the plan the burden of showing that the changes are fair, just and equitable. If this burden had been left on the complaining stockholder, the result would probably be no improvement over the Delaware tests.

${ }^{26}$ The above facts and data are taken from the company's "Proposal of Compromise or Arrangement" (Nov. 12, 1947).

${ }^{27}$ Re St. Lawrence Corp. and Mayr, [1948] 2 D.L.R. 107 (Quebec Super. Ct.). The court also disapproved the plan on the further ground of inadequate information given to the stockholders; from that angle, too, the case merits comparison with American decisions.

${ }^{28}$ The Companies Act, 11 \& $12 \mathrm{Geo}$. VI, c. $38, \S \S 206,72$ (1948). These sections continue the similar provisions in The Companies Act, $19 \& 20 \mathrm{Geo}$. V, c. 23, \$§ 153, 61 (1929).

28a Op. cit. supra note 9.

29 Neb. I. (1951) c. 42, § 5; 3 P-H Corp. Serv. Neb. 24-A (1951). 
A possible flaw in the Nebraska legislation is its failure to make a similar provision for the merger cases. Perhaps the draftsmen found it awkward to draft a provision that would distinguish between a legitimate merger and one used merely to alter seniors' rights. Possibly they hoped that an alert court, impressed by the legislative policy behind this statute, would not be lured into a Havender decision..$^{30} \mathrm{~A}$ possible solution would be to provide that a stockholder whose relative rights were altered by a parent-subsidiary merger should have the same remedies he would have had were the changes made by direct charter amendment.

This type of judicial scrutiny is less open to the charge of burdening the courts than the first type described above, unless doing a better job of weighing the respective give-and-take under the plan is a burden too heavy for judicial shoulders. The Nebraska legislature apparently felt otherwise, and properly I would say.

3. Legislation might forbid any change in the preferences of senior shares without unanimous consent, either of the whole class or of those of the class actually voting. A Massachusetts statute provides, with respect to charter amendments changing shares from par to no par, "the preferences, voting powers, restrictions and qualifications of the outstanding shares so changed or exchanged, shall not be otherwise impaired or diminished without the consent of the holders thereof."31 The theory of this statute might be extended beyond its limited scope. However, such rigidity appears undesirable. It is preferable that greater power be granted if that power is coupled with appropriate safeguards.

4. Veto power over unfair recapitalizations might be given to state blue sky commissions by defining, in the state's blue sky statute, a sale to include "any change in the rights, preferences, privileges or restrictions on outstanding securities," as is done in the California statute. ${ }^{32}$ Under most blue sky laws, as well as under the Federal Securities Act of 1933, a change in existing shares effected by fundamental corporate changes or by an exchange of new shares for existing shares is either deemed not a "sale" or is specifically exempt. The theory is that high pressure salesmanship and promotional activity are absent. ${ }^{33}$ However, the California legislative attitude is much more realistic. Once a substantial change in existing securi-

${ }^{30}$ Federal United Corp. v. Havender, 24 Del. Ch. 318, 11 A. 2d 331 (Del. S. Ct., 1940).

315 Mass. Ann. Laws (1948) c. 156, $\$ 41$.

${ }^{32}$ Calif. Corp. C.A. (Deering, Supp., 1951) \$25009(a). Dahlquist, Regulation and Civil Liability Under the California Corporation Securities Act: II, 34 Calif. L. Rev. 344, 350-62 (1946).

${ }^{33}$ Dahlquist, ibid, at 350 . 
ties is legislatively treated like a non-exempt sale, the blue sky commissioners in many states have power to withhold permission to make the sale if they find that it would not meet the statutory standards, such as "fair, just and equitable" (California), not "fraudulent" nor "contrary to good business practices" (North Carolina), not "grossly unfair" nor such as "would tend to defraud or deceive" (Ohio), etc. The language of many of the statutes could be improved, in the general direction of the California terminology. However, prospects for solution through blue sky laws are not too bright. Many states have no blue sky law of the regulatory type and would be unlikely to change for the sake of senior shareholders; and in many states that do have an apparently effective law, the administration does not attain the high standard of, say, the California commission.

5. The statutes relating to dividends might be amended to permit corporations to pay dividends on preferred shares out of profits of the current or preceding fiscal period despite lack of surplus. ${ }^{34} \mathrm{I}$ am not impressed with the argument that granting the directors this power is dangerous; first, it virtually exists anyhow, since management has no difficulty in getting common to vote for a capital reduction when the reduction serves the latter's interests; second, some states, such as California ${ }^{35}$ and Delaware, ${ }^{36}$ now permit dividends out of current profits despite a deficit, and it does not appear that this has led to even such abuses as are theoretically possible in other states by deficit-eliminating capital reductions; third, if management's power is to be checked, the assent of the preferred (but not that of the juniors) might be made a condition of dividend distributions; fourth, if there is really a sincere desire to protect creditors and others who might be injured by such distribution, this proposal offers far more protection than the capital reduction statutes now provide. Protection could be afforded by prohibiting a distribution which would impair a prescribed "current ratio," or overall ratio of assets to indebtedness. ${ }^{37}$

Permission to pay dividends to seniors out of current earnings should be accompanied by a clear prohibition against charter clauses, which would

34 This suggestion is made by Dodd, op. cit. supra note 22, at 42 .

${ }^{35}$ Calif. Corp. C.A. (Deering, 1948) $\S 1500(b)$. This section, however, forbids dividends to juniors which would impair the liquidation preferences of seniors.

${ }^{26}$ Del. Corp. Law $\$ 34$, Del. Rev. Code (1935) c. 65, $\S 2066$. But dividends cannot be paid (even to seniors) if seniors" "capital" is or would be impaired.

${ }^{37}$ Such a prescribed ratio exists, for instance, in North Carolina, N.C. Gen. Stat. (1950) \$55-116. The ratio there required, three-to-two, perhaps should be increased by the legislature to two-to-one, or better. 
restrict the dividend fund, lest the purpose of the legislation be defeated. ${ }^{38}$ The constitutionality of such legislation, even as to pre-existing charters, would seem reasonably clear, particularly under the "reserved power" clause in state statutes, not to speak of recent doctrinal developments in the field of "police power."

6 . An awkward way to reach the same result is to amend the capital reduction statutes so as to permit reduction by the vote of the preferred alone wherever the existence of a deficit prevents immediate payment of dividends out of current or prospective profits. Certainly there could be no objection from other classes if the capital reduced is that of the senior class itself. Indeed, one should go further and even permit, by senior's vote alone, the reduction of junior capital. It is not self-evident that juniors must have the right to insist that impairment of capital be eliminated before dividends can be paid on the senior class. To permit the seniors to vote for a reduction of that mere book entry "capital" is, to the extent that a deficit is eliminated, merely to permit them to reflect the truth, viz. that the junior's equity has been thinned down.

7. Another legislative possibility lies in compulsory shifting of voting power to the senior shareholders upon repeated failure to pay dividends. Statutory precedent can be found in the Investment Company Act of 1940 , which, as to certain investment companies, makes it unlawful to issue preferred shares unless provision is made to entitle the preferred shareholders to elect at least two directors in any event and to elect a majority whenever two full years' dividends on the preferred are unpaid..$^{39}$ Judicial decisions recognizing the state's power, under the "reserved power," to change previously established voting arrangements indicate that such a statute would survive attacks on constitutional grounds. ${ }^{40}$

The main argument against this solution is that such a statute would be largely futile. Short of a proxy fight, the statute would not bring about a new directorate imbued with a strong desire to protect seniors, particularly in corporations with numerous stockholders where the proxy machinery works at its smoothest. In the Denver Tramway case, pursuant to a charter

${ }^{38}$ Cf. Barrett v. Denver Tramway Corp., 53 F. Supp. 198 (D. Del., 1943), aff'd, 146 F. 2d 701 (C.A. 3d, 1944).

${ }^{39}$ Investment Company Act of 1940, $\S 18(\mathrm{a})(2)(\mathrm{C}), 54$ Stat. 817 (1940), 15 U.S.C.A. $\S 80 \mathrm{a}-18(\mathrm{a})(2)(\mathrm{C})(1951)$.

${ }^{40}$ Looker v. Maynard, 179 U.S. 46 (1900) (later statute conferred cumulative voting rights on stockholders in a pre-existing corporation previously not entitled to vote cumulatively). The State's constitutional powers to amend the corporate contract by imposing an amendment having a rational basis is perhaps even clearer than when the state has granted the amending power to the majority stockholders. See Note, 54 Harv. L. Rev. 1368-69 (1941). 
clause, voting power had passed to the preferred by virtue of unpaid dividend accumulations, ${ }^{41}$ but that did not prevent managerial sponsorship of a highly questionable plan. ${ }^{42}$

8. Combining several of the above proposals, one might go further and provide that when preferred stock dividends have been in arrears for a fairly long term of years, a relatively small percentage of the preferred shareholders may petition the court for a recapitalization. The court would have power to require the corporation to act pursuant to a judicially approved plan that would fairly reflect the investment position in the enterprise of the various classes of shares and distribute voting power in accordance with that position. This would eliminate the absurdity of a hopelessly "under water" class of common still dominating the enterprise.

Although this idea is not without legislative analogy, ${ }^{43} \mathrm{I}$ would not care to see the seniors swoop down and wipe out the juniors in a period of depression. However, one wonders whether even that would be worse than the present situation. Moreover, the statute could contain safety-valve provisions empowering a court to delay action on a prematurely presented petition. A further safeguard for the common might be to give the preferred this right of judicial petition only when the corporation proposes a plan that would alter the rights of seniors.

9. Another possibility is a statutory requirement that before the shareholders vote on a recapitalization plan, there be sent to shareholders an advisory report by an administrative agency analyzing the plan and commenting upon its fairness. This would be comparable to the advisory report of the Securities and Exchange Commission now provided for under the Investment Company Act of 1940 when registered companies seek to recapitalize. ${ }^{44}$ Even if the commissioners would frequently lack the competence of the SEC, it is perhaps not too naĩve to expect some competence. However, the scheme is weak not so much because a poor unfavorable report will kill a meritorious plan as because a poor favorable report might

41 Barrett v. Denver Tramway Corp., 146 F. 2d 701, 703 (C.A. 3d, 1944).

42 Professor Dodd has characterized the interplay of the legal doctrines which permit the consummation of plans like the one in that case as "a reproach to any system of law that professes to be a civilized system." Dodd, op. cit. supra note 22, at 39.

43 Public Utility Holding Company Act of 1935, § 11(b)(2), 49 Stat. 821 (1935), 15 U.S.C.A. $\$ 79 \mathrm{k} \mathrm{(b)(2)(1951).} \mathrm{A} \mathrm{registered} \mathrm{utility} \mathrm{can} \mathrm{be} \mathrm{compelled} \mathrm{by} \mathrm{court} \mathrm{order} \mathrm{(or} \mathrm{can} \mathrm{itself} \mathrm{take} \mathrm{the}$ initiative) to take such steps as the Securities and Exchange Commission finds necessary to ensure that the corporate structure does not "unfairly and inequitably distribute voting power among security holders."

4s Investment Company Act of 1940, $\$ 25(\mathrm{~b}), 54$ Stat. 826 (1940), 15 U.S.C.A. $\$ 80 \mathrm{a}-$ 25(b) (1951). The SEC also submits an advisory report in certain circumstances in reorganizations under Chapter X of the Bankruptcy Act, 30 Stat. 544 (1898), as amended, 11 U.S.C.A. $\$ 572$ (1946). 
make it virtually impossible to have a challenged plan struck down by the courts.

10. As an alternative method for informing shareholders as to the proposed plan, a statute might provide: (a) before solicitation there shall be sent to each stockholder a copy of the proposed plan coupled with a notice of a hearing to be held on the necessity and fairness of the plan; (b) full opportunity shall be given at the hearing to voice objections to the plan or to propose other plans; (c) no later than a designated number of days before voting, and before or contemporaneously with the solicitation of proxies, the corporation shall send to the shareholders the written objections made by any stockholder who within, say, ten days from the conclusion of the hearing delivers his written objections to the corporation; (d) the expense of printing and mailing shall be borne by the corporation; (e) a copy of this statutory provision be enclosed with the notice of hearing on the plan. To guard against harassment, the statute could limit the word-length of the objection to be mailed and restrict the right of demand to those who have been stockholders for a prescribed period of time. Conceivably, hearings could be dispensed with and the corporation required to distribute the written objections of the shareholders.

Except that the corporation bear the expense of printing and mailing, the foregoing scheme is comparable to the SEC's proxy regulations requiring management to mail out (or to give the shareholder the information that would enable the shareholder to mail out) proxy statements containing shareholders' communications and requiring management to set forth the reasons advanced by a shareholder in support of a shareholder's proposal that is opposed by management. ${ }^{45}$

11. State legislation could take the guise of a proxy regulation designed to give the shareholder adequate information about the transaction that he is to be asked to vote on. The underlying philosophy would be like that of the SEC proxy regulations. The statute could provide that in solicitation of proxies by management with respect to voting on a plan involving modification of the rights of any outstanding senior shares, the solicitation literature be required to give detailed information on the need for the modification, the precise extent of the sacrifice which senior shares would be called upon to make, and the reason why various clearly specified alternative methods could not be utilized. ${ }^{46}$

${ }^{45}$ SEC Rules X-14A-7 and X-14A-8, 17 Code Fed. Regs. $\$ \$ 240.14 a-7,240.14 a-8$ (1949).

46 The information provided would include the following:

1) If the stated need for recapitalization is the facilitation of corporate financing,

a) the plans for reasonably immediate financing entertained by management, and

b) how the present capitalization impedes such financing. 
12. As an alternative the $\mathrm{SEC}$ might modify its present rules to require a proxy statement giving specific information, the requirements for which would be set out with particularization in the rules. The present SEC rules relating to solicitation of proxies for recapitalization are inadequate. They contain very general directions, such as "describe any material differences between the outstanding securities and the new or modified securities"; 47 and "state the reasons for the proposed modification,"48 and "[o]utline briefly the material features of the plan." 49 What is needed is a set of proxy rules drafted with a sharp eye on the pressure points for getting votes for sacrificial plans. Of course, SEC regulations would only affect recapitalizations involving securities listed on the registered national stock exchanges. Even that would be a help; and, conceivably, success there might set the pattern for state legislation.

13. A minimal statutory improvement would be to require vote by classes of shareholders on any modification of outstanding securities, irrespective of whether the class is otherwise non-voting. At the present time, statutes generally do not require vote by classes on mergers, despite the fact that merger with subsidiaries is a favorite way of altering share-

2) If the stated need for recapitalization is the elimination of deficits to pave the way for payment of dividends,

a) whether, in the opinion of counsel, it would be legally possible to pay dividends without a modification of rights by reducing the par or stated value of the outstanding shares, or any class thereof, by the amount of the deficit, and

b) if counsel's opinion is in the affirmative, give the reasons why management has made no efforts, or expects to make no efforts, to effect such a capital reduction.

3) The net income available for dividends over the preceding six and twelve month periods.

4) On the basis of (independently?) prepared studies, the range of reasonably anticipated future net income and, assuming all such income is to be distributed as dividends, the amount which would be received by the holder of a share of each class of stock under both present and proposed capitalizations.

5) The amount of annual future net income which would, in the opinion of the Board of Directors, justify the relative claims upon earnings which existing classes of stock would have under the new plan as against what they had under the old, including, of course, an explanation of the result and a statement of whether, in the opinion of the Board of Directors, this amount of income can reasonably be expected.

6) Full statements of appraisal rights including a statement of whether management intends to take the position, in the event of demand for appraisal, that the value is less than the liquidation priority, and if so why. (1949).

${ }^{47}$ SEC Regulation X-14, Schedule 14A, item 13(b), 17 Code Fed. Regs. 235, item 13(b)

18 SEC Regulation X-14, Schedule 14A, item 13(c), 17 Code Fed. Regs. 235, item 13(c) (1949).

${ }^{49}$ SEC Regulation X-14, Schedule 14A, item 14(a), 17 Code Fed. Regs. 236, item 14(a) (1949). 
holders' rights. In some states, either there is no vote by classes on a charter amendment ${ }^{50}$ or the vote on even fundamental changes is given only to voting shares. ${ }^{51} \mathrm{I}$ hasten to emphasize that this suggested improvement is indeed minimal in the light of previous comments in this paper, and, without more would be quite futile.

14. Finally, there is a statutory possibility which I mention last because, although it may appear at first glance to be an easy and just solution, its real value is quite doubtful. The suggestion is: give the dissenter the right of appraisal and buy him out. That right is now given by the merger statutes in almost every state; let it be extended to any fundamental change that alters shareholders' rights, whether by charter amendment or by the merger device. As a cumulative remedy, well and good; but as a basic solution, buying-out is not satisfactory. First, it is no help to nonobjectors who cast their affirmative vote under the pressures heretofore discussed; second, it is reminiscent of the impatient answer often made to social critics: "if you don't like it here, go somewhere else"; third, as the appraisal right works out, it is doubtful that the senior's investment position is truly reflected in the appraisal price. This is illustrated by the dissenters in the York Ice Machinery Corporation's arrearage elimination merger. They were unsuccessful in enjoining a recapitalization which, by changing existing preferred and common into a single class of common, recognized the common as a 17 per cent owner of the enterprise. ${ }^{52}$ The plan, therefore, viewed the enterprise as having value in excess of the priorities of the $\$ 100$-par preferred with its arrearages of $\$ 88.28$ per share; it was not a case where a class of preferred has a low "investment value" because of a low dividend rate. When the dissenting preferred shareholders exercised their appraisal rights, they were paid off at $\$ 90$ per share. ${ }^{53} \mathrm{Ap}$ parently the corporation was able to convince two of the appraisers ${ }^{54}$ that the values in the enterprise came nowhere near the preferred's priority of par plus arrearages. When the appraisal was challenged in court, the Chancellor conceded that "it is, therefore evident that the corporation did claim in the injunction suit that the common stock of

50 E.g., N.C. Gen. Stat. (1950) §55-31.

51 E.g., N.C. Gen. Stat. (1950) §55-61 dealing with the creation of a new class of shares with priorities over existing senior shares.

s2 Hottenstein v. York Ice Machinery Corp., 136 F. 2d 944 (C.A. 3d, 1943).

${ }^{53}$ Root v. York Corp., 22 Del. Ch. 351, 50 A. 2d 52 (1946); see also Hottenstein v. York Ice Machinery Corp., 146 F. 2d 835 (C.A. 3d, 1944).

54 The third appraiser (the one appointed by the dissenter, presumably) valued the dissenter's shares at $\$ 197.50$ but the valuation of the other two appraisers prevailed. Root $v$. York Corp. 22 Del. Ch. 351, 50 A. 2d 52 (1946). 
York Ice Machinery Corporation had some equity, while before the appraisers it claimed that the value of the preferred stock was worth less than par and the accumulated dividends thereon." 55 But, continued the Chancellor, "estoppel based on a species of fraud is not applicable." If this is a sample of what the dissenter is up against, the appraisal remedy offers little promise in seeking an answer to unfair recapitalizations. It may be significant that the recent Nebraska legislation concerning charter amendments gives the right to challenge the modification plan for fairness as well as the right to appraisal..$^{57}$

\section{Summary}

Some of the enumerated legislative possibilities would not go far toward coping with the peculiar problems of recapitalization plans altering the relative rights of senior shares. However, even those palliatives would be an improvement. Some of the other proposals are perhaps too labored and unwieldy when weighed against the maladjustments that need correction in this area of corporation law. After all, no disaster will befall the corporate economy even if the "recapitalization racket" (to use Professor Dodd's term ${ }^{58}$ ) continues to function as before. Of the remaining possibilities, there is no perfect remedy-no easy, sure, painless inexpensive cure, free of any danger of overdose. My own inclination would be to combine, experimentally, several of the above enumerated proposals: give the shareholder who deems himself aggrieved the right to challenge the capitalization in court for lack of fairness (as in the recent Nebraska legislation but with the merger loophole closed); give him also the right of appraisal (again, as in Nebraska); permit a corporation to pay dividends on senior shares from earnings of an appropriately circumscribed current or preceding fiscal period despite a deficit; and, I am tempted to add, upon two years of arrearages give the seniors power to elect a majority of the directors; finally let the Securities and Exchange Commission re-examine its proxy rules to see whether it would not be possible to devise detailed rules better attuned to the facts of life in recapitalization solicitations.

65 Ibid., at 58.

${ }^{67}$ Neb. L. (1951) c. 42, § 5; 3 P-H Corp. Ser. Neb. 24-A (1951).

58 Op. cit. supra note 22. 